\title{
Pneumocystis Jirovecii Pneumonia in HIV-Infected Patients: A Single Center Experience
}

\author{
(iD) Heval Can Bilek¹, (DD) Aydın Deveci², (iD) Esra Tanyel ${ }^{3}$ \\ ${ }^{1}$ MD Spec., Ondokuz Mayis University Faculty of Medicine Department of Infectious Diseases and Clinical Microbiology, \\ Samsun,Türkiye \\ ${ }^{2}$ Assoc. Prof., Ondokuz Mayis University Faculty of Medicine Department of Infectious Diseases and Clinical Microbiology, \\ Samsun,Türkiye \\ 3 Prof., Ondokuz Mayis University Faculty of Medicine Department of Infectious Diseases and Clinical Microbiology, \\ Samsun,Türkiye
}

\section{$\ddot{0} z$}

HIV ile Enfekte Hastalarda Pneumocystis Jirovecii Pnömonisi: Tek Merkez Deneyimi

Amaç: Pneumocystis jirovecii pnömonisi (PCP), insan immünyetmezlik virüsü (HIV) ile enfekte ileri evre hastalarda ve antiretroviral tedavilerine uymayan kişilerde hala kritik bir fırsatçı enfeksiyondur. Bu çalıșma, HIV ile enfekte hastalarda gelișen PCP enfeksiyonlarının klinik ve tanısal özelliklerini değerlendirmeyi amaçlamaktadır.

Yöntem: Ocak 2005 ile Mart 2020 arasında üniversite hastanesinde izlenen 18 yaș ve üstü HIV ile enfekte hastaların tıbbi kayıtları geriye dönük olarak incelendi.

Bulgular: Çalıșma kapsamında; 62’si (\%15,6) kadın, 335’i (\%84,4) erkek ve yaş ortalaması 39,2 \pm 11,6 yıl olan 397 HIV ile enfekte hasta değerlendirildi. Yaș, PCP'yi gelişimi açısından bir risk faktörü olarak bulunmasa da erkek cinsiyet risk faktörü olarak saptandı. PCP'li hastalar, PCP'si olmayan hastalara göre önemli ölçüde daha düşük CD4 lenfosit sayılarına sahipti ve CD4 lenfosit sayısının <200/mm3 olması, hastalık riskini önemli ölçüde arttırmaktaydı. Hastaların başvuru anında en yaygın sistemik șikâyeti ateș, en sık görülen solunum yolu șikâyeti ise öksürüktü. Hastaların \%57,1'inde immünofloresan antikor (IFA) testi pozitifti. Tüm hastaların gögüs tomografisinde PCP'yi destekleyen görünümler saptandı.

Sonuç: İleri düzeyde immün yetmezliği olan HIV ile enfekte erkek hastalar, PCP gelişimi için yüksek riskli olarak değerlendirildi. Tipik klinik bulguların varlığında, göğüs tomografisi ve mikrobiyolojik tanı testlerinin birlikte değerlendirilmesinin doğru klinik tanı için yararlı olduğu saptandı. Anahtar Kelimeler: Human Immunodeficiency Virus, Edinilmiș İmmün Yetmezlik Sendromu, Pnömosistis

\section{Abstract}

Pneumocystis Jirovecii Pneumonia in HIV-Infected Patients: A Single Center Experience

Objective: Pneumocystis jirovecii pneumonia (PCP) is still a critical opportunistic infection in patients diagnosed with the human immunodeficiency (HIV) infection in the advanced stages and patients who do not adhere to antiretroviral therapy. This study aimed to evaluate the clinical and diagnostic features of PCP infections developed in HIV-infected patients.

Methods: HIV-infected patients aged 18 years and older, followed between January 2005 and March 2020 at the university hospital, were retrospectively reviewed from medical records.

Results: Within the study's scope, 397 HIV-infected patients, 62 (15.6\%) females and 335 (84.4\%) males, with a mean age of $39.2 \pm 11.6$ years, were evaluated. While age was not a risk factor for developing PCP, the male gender was a risk factor. Patients with PCP had significantly lower CD4 lymphocytes counts than patients without PCP, and a CD4 lymphocyte count $<200 / \mathrm{mm} 3$ significantly increased the disease's risk. The patients' most common systemic complaint was fever at the time of presentation, and the most common respiratory complaint was cough. The immunofluorescent antibody (IFA) test was positive in $57.1 \%$ of the patients. All patients had appearances that might be supportive for PCP in chest tomography.

Conclusion: HIV infected male patients with advanced immunodeficiency constituted a high-risk group for developing PCP. In the presence of typical clinical findings, the evaluation of chest tomography and microbiological diagnostic tests together were found to be useful for accurate clinical diagnosis.

Keywords: Human Immunodeficiency Virus, Acquired Immunodeficiency Syndrome, Pneumocystis

Nasıl Atıf Yapmalı / How to cite: Bilek HC, Deveci A, Tanyel E. Pneumocystis jirovecii pneumonia in HIV-infected patients: A single-centre experience. MKÜ Tıp Dergisi. 2021;12(43):131-135. https://doi.org/10.17944/mkutfd.911354

Sorumlu Yazar/Corresponding Author: MD Spec., Heval Can Bilek

Geliş/Received: 7 Nisan 2021

Email: hevalcan.bilek@omu.edu.tr

Kabul/Accepted: 29 Temmuz 2021

ORCID iD: 0000-0002-4330-3293 


\section{INTRODUCTION}

Pneumocystis species are unicellular fungi that can be found in the lungs of many mammals. Five species have been identified: Pneumocystis jirovecii in humans, $P$. carinii and $P$. wakefieldiae in rats, $P$. murina in mice, and $P$. oryctolagi in rabbits (1). P. jirovecii is the cause of Pneumocystis jirovecii pneumonia (PCP), which causes significant morbidity and mortality, especially in Human immunodeficiency virus (HIV) infected and among immunocompromised patients (2). Diagnosis can be challenging due to its non-specific clinical symptoms. In mild cases, radiological findings may be non-specific and even routine, which makes the high clinical suspicion the most important diagnostic tool for PCP (3). Although the epidemic of HIV infection significantly increased the prevalence of PCP worldwide in the 1980s, PCP incidence in the HIV-infected population has decreased in most developed countries, owing to progress in Antiretroviral therapy (ART) and routine use of prophylaxis against PCP (4). However, PCP remains an important opportunistic infection in those who are not aware of their HIV infection, diagnosed in the advanced stages of the disease and do not adhere to follow-ups $(5,6)$. Clinical studies have shown that if the diagnosis of PCP is delayed, the prognosis can be poor or even fulminant (7). Therefore, we aimed to evaluate the clinical and diagnostic features of PCP infections developed in HIV-infected patients.

\section{MATERIALS AND METHODS}

HIV-infected patients aged 18 years and older, followed between January 2005 and March 2020 at the university hospital, were retrospectively reviewed from medical records.

The diagnosis of PCP was established based on the presence of typical clinical findings in an HIV-infected patient who has supporting radiological findings in chest computed tomography $(\mathrm{CT})$ and/ or detection of P. jirovecii antigens with immune fluorescence antibody (IFA) method in respiratory samples with a commercial kit (Merifluor Pneumocystis, Meridian Bioscience, Inc., Cincinnati, Ohio).

Trimethoprim/sulfamethoxazole was orally or intravenously initiated for all clinically suspected patients with a dosage of $15-20 \mathrm{mg} / \mathrm{kg} /$ day in three or four divided doses based on the trimethoprim component. Additional corticosteroid therapy was also given along with PCP therapy.

\section{Statistical Analysis}

SPSS software version 21 (SPSS Inc., Chicago, IL, USA) was used for statistical analysis. Normality tests were performed using Kolmogorov-Smirnov and Shapiro-Wilk tests. Categorical variables were compared between groups with either the chi-square test or the Fisher exact test. Binary logistic regression analysis was performed to determine the predictive factor for CD4 T lymphocyte count.

\section{RESULTS}

A total of 397 HIV-infected patients, including 62 (15.6\%) females and 335 (84.4\%) males, were reviewed in the study's scope. The mean age was $39.2 \pm 11.6$ years. PCP was diagnosed in 20 (5\%) patients. There was no statistically significant difference between the mean age of the patients with and without PCP $(43,3 \pm 9,9$ vs $38,9 \pm 11,7$ years, respectively) $(p>0,05)$. The mean CD4 cell count at the time of diagnosis was $524 \pm 281$ cells/mm3 in women and $406 \pm 288$ cells/ $\mathrm{mm} 3$ in men. The difference in the mean count of CD4 T lymphocytes between genders was statistically significant ( $p$ $<0.05)$.

\begin{tabular}{|c|c|c|c|c|c|}
\hline \multirow{3}{*}{$\begin{array}{l}\text { Number of patients } \\
(\%)\end{array}$} & \multicolumn{2}{|c|}{ PCP-positive } & \multicolumn{2}{|c|}{ PCP-negative } & $p$ \\
\hline & $\mathrm{n}$ & $\%$ & $\mathrm{n}$ & $\%$ & \multirow{2}{*}{ NA } \\
\hline & 20 & 5 & 377 & 95 & \\
\hline Age (mean) / years & \multicolumn{2}{|c|}{$43.3 \pm 9.9$} & \multicolumn{2}{|c|}{$38.9 \pm 11.7$} & $p>0.05$ \\
\hline $\begin{array}{c}\text { Gender (Female / } \\
\text { Male) }\end{array}$ & \multicolumn{2}{|c|}{$1 / 19$} & \multicolumn{2}{|c|}{$61 / 316$} & $p<0.05$ \\
\hline $\begin{array}{l}\text { CD4 T lymphocyte } \\
\text { mean count / mm }\end{array}$ & \multicolumn{2}{|c|}{$169 \pm 202$} & \multicolumn{2}{|c|}{$425 \pm 290$} & $p<0.01$ \\
\hline \multicolumn{6}{|c|}{$\begin{array}{l}\text { PCP: Pneumocystis jirovecii pneumonia. A p-value less than } 0.05 \\
\text { (typically } \leq 0.05 \text { ) is statistically significant. } \\
\text { NA: Not applicable }\end{array}$} \\
\hline
\end{tabular}

Table 2. The most common clinical symptoms and chest OT findings in PCP patients.

\begin{tabular}{|l|c|c|}
\multicolumn{1}{|c|}{ Clinical Symptoms } & n & $\%$ \\
\hline Fever & 11 & 55 \\
\hline Cough & 10 & 50 \\
\hline Sputum production & 9 & 45 \\
\hline Weight loss & 9 & 45 \\
\hline Shortness of breath & 7 & 35 \\
\hline \multicolumn{1}{|c|}{ Radiograph/ Chest CT features } & n & $\%$ \\
\hline Bilateral diffuse ground-glass density & 14 & 70 \\
\hline Bilateral diffuse irregular alveolar densities & 3 & 15 \\
\hline Bilateral diffuse paving-stone appearance & 1 & 5 \\
\hline $\begin{array}{l}\text { Diffuse panacinar irregular nodular infiltration in } \\
\text { the left lung }\end{array}$ & 1 & 5 \\
\hline $\begin{array}{l}\text { Right-sided pleural effusion and bilateral } \\
\text { minimal septal thickening }\end{array}$ & 1 & 5 \\
\hline
\end{tabular}


Of the patients diagnosed with PCP, 19 (95\%) were male, and one (5\%) was female. Male gender was found to be a risk factor for PCP development (odds ratio: 1.13; 95\% confidence interval: 1.01-1.26).

Fourteen patients (70\%) with PCP were ART-naive, and six (30\%) patients were ART experienced. Among ART experienced patients, two had virologic suppression (HIV-Ribonucleic acid (RNA) $<50$ copy $/ \mathrm{ml}$ ) and four patients had a virologic failure due to non-adherence to ART.

At the time of PCP diagnosis, patients with PCP had significantly lower CD4 lymphocytes counts than patients without PCP $(169 \pm 202$ cells $/ \mathrm{mm} 3$ vs $425 \pm 290$ cells $/ \mathrm{mm} 3)(p<0.01)$. The CD4 T lymphocyte count $<200$ cells/ $\mathrm{mm} 3$ increased the risk of developing the PCP by 3.17 times (95\% confidence interval: 2.24-4.49).

The patients' most common systemic complaint was fever at the time of presentation, and the most common respiratory system complaint was cough.

The median duration between the emergence of PCP-related systemic and respiratory complaints and the diagnosis was 60 days $(\min =5$ and $\max =360)$.

Induced sputum samples of 13 patients and bronchoalveolar lavage (BAL) sample of one patient were examined by immune fluorescence antibody (IFA) method, and $P$. jirovecii antigens were detected in eight (57.1\%) patients.

The most frequently reported radiological finding in chest CT was "Bilateral diffuse ground-glass density".

Eighteen (90\%) patients recovered, whereas 2 (10\%) patients have died before the completion of treatment.

\section{DISCUSSION}

According to the Turkish Ministry of Health data, 26447 HIV infected and 1974 acquired immunodeficiency syndrome (AIDS) cases identified between 1985 and Jan 31, 2021, in Turkey. Of these patients, $81.05 \%$ were male, and $18.95 \%$ were female, mainly in the 30-39 age group (8). The gender distribution and average age of the patients in this study are similar to the national data.

PCP mainly develops in HIV infected patients with a CD4 lymphocyte count below $200 / \mathrm{mm} 3$ and whose infection is not under control (9). Of the study patients, $89.4 \%$ had severe immunosuppression (CD4 lymphocyte count $<200 / \mathrm{mm} 3$ ) and in accordance with the general literature, it was found that low CD4 count as a risk for developing PCP.

The male gender found to be a risk for developing PCP in this study. We think that the most important reason to explain the impact of gender is the significantly lower CD4 lymphocyte counts among men compared to women. It seems that men apply for health care in the advanced stages of disease when HIV-related immune deficiency already occurred.

The clinical appearance of PCP does not differ from infective and non-infective pulmonary or cardiopulmonary diseases. The clinic typically manifests fever and shortness of breath associated with a non-productive cough $(10,11)$. While the disease may progress to life-threatening hypoxia in a few days, clinical manifestations are generally mild at first presentation in HIV infected patients. Patients usually complain of chest discomfort, exercise intolerance, low-grade fever, and cough persisting for several weeks. (12). The average duration of symptoms before diagnosis in HIV infected patients reported being 21 to 30 days compared to five to seven days in non-HIV-infected individuals $(11,13,14)$. In this study, the most common clinical symptoms and signs of patients at the time of diagnosis were fever, cough, and sputum production, respectively. Although sputum production in PCP is not a typical clinical finding, when taking patients' history, recording cough and sputum production as a single clinical finding by physicians might have caused more frequent reporting of sputum production among patients. The 60-day median time between the occurrence of patients' clinical complaints and the diagnosis of the disease was longer than the periods reported in the literature. But, $75 \%$ of patients diagnosed with PCP have consisted of patients who applied late stage to healthcare, which may be why the longer duration of symptoms before the diagnosis in the study.

Since $P$. jirovecii cannot be grown in culture, microscopic imaging and/ or deoxyribonucleic acid (DNA) amplification of cysts or trophozoite forms in respiratory samples is standard procedures for detecting the microorganism (15-17). When IFA test kits of $P$. jirovecii were available in our laboratory, the antigen belonging to the agent was detected in $57.1 \%$ of patients' respiratory sample. In a previous study conducted in our hospital, positivity was detected in $54 \%$ of the respiratory tract samples of 255 patients, including HIV-infected patients (18). Collecting a BAL sample with bronchoscopy is considered the gold standard procedure for diagnosing PCP in HIV-infected patients (19). But pulmonary samples obtained by invasive techniques such as bronchoscopy carry a risk of complications when sampling and are not easy to obtain in patients with respiratory failure $(20,21)$. The microscopic examination of BAL samples in HIV-infected patients has a sensitivity of 98\% or higher while induced sputum with a diagnostic efficiency of $50-90 \%$ in the diagnosis of PCP $(19,21)$. Induced sputum samples were examined more frequently in our clinic, both because of the clinician's preference since the patients had severe immunosuppression and because the patients generally did not consent for an invasive procedure. This reason may explain why the low microbiological identification rate in the present study. 
Chest CT is the most appropriate radiological examination to aid in diagnosing PCP and should be considered in the early stages of the disease, even if the chest X-ray is normal (22). In the chest CT, PCP typically reveals bilateral groundglass opacity (22). Other findings may include nodules, cystic lesions, pneumothorax, and pneumomediastinum, while unilateral involvement may sometimes occur (23-25). In this study, the most frequently reported radiological findings in HIV-infected patients with typical clinical symptoms had also been "Bilateral diffuse ground-glass density", as expected. Evaluating the clinical history and clinical findings together, the chest CT results found to be supportive for diagnosis in all patients.

\section{CONCLUSION}

After implementing PCP prophylaxis, the incidence of PCP decreased significantly. However, despite the main ART-related benefits, PCP continues to be one of the most common causes of AIDS-related deaths. Late presentation was still common in the patients we followed. HIV infected male patients with advanced immunodeficiency constituted the leading risk group for developing PCP. In the presence of clinical findings, performing chest CT and microbiological diagnostic tests together was beneficial in making a proper diagnosis.

\section{ACKNOWLEDGEMENT}

Peer-Review

Externally Peer Reviewed

Conflict of Interest

The authors declare that they have no conflict of interests regarding content of this article.

Financial Support

The Authors report no financial support regarding content of this article.

\section{Ethical Declaration}

Ethical approval was obtained from 19 Mayıs University Clinical Research Ethical Committee with date 25/06/2020 and number 2020/437, and Helsinki Declaration rules were followed to conduct this study.

\section{REFERENCES}

1. Ma L, Cissé OH, Kovacs JA. A Molecular Window into the Biology and Epidemiology of Pneumocystis spp. Clin Microbiol Rev. 2018;31(3):e00009-18. https://doi.org/10.1128/CMR.00009-18

2. Otieno-Odhiambo P, Wasserman S, Hoving JC. The Contribution of Host Cells to Pneumocystis Immunity: An Update. Pathogens. 2019;8(2): 52. https://doi.org/10.3390/ pathogens8020052

3. Salzer HJF, Schäfer G, Hoenigl M, Günther G, Hoffmann C, Kalsdorf B, Alanio A, Lange C. Clinical, Diagnostic, and Treatment Disparities between HIV-Infected and Non-HIVInfected Immunocompromised Patients with Pneumocystis jirovecii Pneumonia. Respiration. 2018;96(1): 52-65. https:// doi.org/10.1159/000487713
4. Pereira-Díaz E, Moreno-Verdejo F, de la Horra C, Guerrero JA, Calderón EJ, Medrano FJ. Changing Trends in the Epidemiology and Risk Factors of Pneumocystis Pneumonia in Spain. Front Public Health. 2019;7: 275. https://doi.org/10.3389/ fpubh.2019.00275

5. Lapadula G, Cozzi-Lepri A, Marchetti G, Antinori A, Chiodera A, Nicastri E, Parruti G, Galli M, Gori A, Monforte Ad; ICONA Foundation Study. Risk of clinical progression among patients with immunological nonresponse despite virological suppression after combination antiretroviral treatment. AIDS. 2013;27(5): 769-79. https://doi.org/10.1097/ QAD.0b013e32835cb747

6. Chow JY, Alsan M, Armstrong W, del Rio C, Marconi VC. Risk factors for AIDS-defining illnesses among a population of poorly adherent people living with HIV/AIDS in Atlanta, Georgia. AIDS Care. 2015;27(7): 844-8. https://doi.org/10.108 0/09540121.2015.1007114

7. Lee YT, Chuang ML. Pneumocystis jirovecii pneumonia in AIDS and non-AIDS immunocompromised patients - an update. J Infect Dev Ctries. 2018;12(10): 824-834. https://doi. org/10.3855/jidc.10357

8. Turkey, Ministry of Health. [cited 2021 Jun 02]. Statistics of HIV-AIDS. Available from: https://hsgm.saglik.gov.tr/tr/ bulasici-hastaliklar/hiv-aids/hiv-aids-liste/hıv-aids-istatislik. html

9. Dunbar A, Schauwvlieghe A, Algoe S, van Hellemond JJ, Reynders M, Vandecasteele S, Boelens J, Depuydt P, Rijnders B. Epidemiology of Pneumocystis jirovecii Pneumonia and (Non-)use of Prophylaxis. Front Cell Infect Microbiol. 2020;10:224. https://doi.org/10.3389/fcimb.2020.00224

10. Kovacs JA, Masur H. Evolving health effects of Pneumocystis: one hundred years of progress in diagnosis and treatment. JAMA. 2009;301(24): 2578-85. https://doi.org/10.1001/ jama.2009.880

11. Shibata S, Kikuchi T. Pneumocystis pneumonia in HIV-1infected patients. Respir Investig. 2019;57(3): 213-219. https:// doi.org/10.1016/j.resinv.2019.01.009

12. Siegel M, Masur H, Kovacs J. Pneumocystis jirovecii Pneumonia in Human Immunodeficiency Virus Infection. Semin Respir Crit Care Med. 2016;37(2): 243-56. https://doi. org/10.1055/s-0036-1579556

13. Liu CJ, Lee TF, Ruan SY, Yu CJ, Chien JY, Hsueh PR. Clinical characteristics, treatment outcomes, and prognostic factors of Pneumocystis pneumonia in non-HIV-infected patients. Infect Drug Resist. 2019;12: 1457-1467. https://doi.org/10.2147/IDR. S199761 
14. Roux A, Canet E, Valade S, Gangneux-Robert F, Hamane S, Lafabrie A, Maubon D, Debourgogne A, Le Gal S, Dalle F, Leterrier M, Toubas D, Pomares C, Bellanger AP, Bonhomme J, Berry A, Durand-Joly I, Magne D, Pons D, Hennequin C, Maury E, Roux P, Azoulay É. Pneumocystis jirovecii pneumonia in patients with or without AIDS, France. Emerg Infect Dis. 2014;20(9): 1490-7. https://doi.org/10.3201/eid2009.131668

15. Esteves F, Medrano FJ, de Armas Y, Wissmann G, Calderón EJ, Matos 0. Pneumocystis and Pneumocystosis: first meeting of experts from Latin-American and Portuguese-speaking countries - a mini-review. Expert Rev Anti Infect Ther. 2014;12(5): 545-8. https://doi.org/10.1586/14787210.2014.89 4883

16. Calderón EJ, Gutiérrez-Rivero S, Durand-Joly I, Dei-Cas E. Pneumocystis infection in humans: diagnosis and treatment. Expert Rev Anti Infect Ther. 2010;8(6): 683-701. https://doi. org/10.1586/eri.10.42

17. Pennington K, Wilson J, Limper AH, Escalante P. Positive Pneumocystis jirovecii Sputum PCR Results with Negative Bronchoscopic PCR Results in Suspected Pneumocystis Pneumonia. Can Respir J. 2018; 2018:6283935. https://doi. org/10.1155/2018/6283935

18. Yanık K, Karadağ A, Usta E, Ünal N, Yılmaz H, Hökelek. Evaluation of Respiratory Samples Results of the Direct Fluorescent Antibody Test Sending with Suspicion of Pneumocystis jirovecii Pneumonia to the Parasitology Laboratory of Ondokuz Mayıs University Medical School Between the Years 2003-2011. Türk Mikrobiyol Cem Derg 2012;42(4): 132-136. DOI:10.5222/TMCD.2012.132

19. Wang D, Hu Y, Li T, Rong HM, Tong ZH. Diagnosis of Pneumocystis jirovecii pneumonia with serum cell-free DNA in non-HIV-infected immunocompromised patients. Oncotarget. 2017;8(42):71946-71953. https://doi.org/10.18632/
20. Choo R, Naser NSH, Nadkarni NV, Anantham D. Utility of bronchoalveolar lavage in the management of immunocompromised patients presenting with lung infiltrates. BMC Pulm Med. 2019;19(1):51. https://doi. org/10.1186/s12890-019-0801-2

21. Prebil SE, Andrews J, Cribbs SK, Martin GS, Esper A. Safety of research bronchoscopy in critically ill patients. J Crit Care. 2014;29(6): 961-4. https://doi.org/10.1016/j.jcrc.2014.06.006.

22. Mu XD, Jia P, Gao L, Su L, Zhang C, Wang RG, Wang GF. Relationship between Radiological Stages and Prognoses of Pneumocystis Pneumonia in Non-AIDS Immunocompromised Patients. Chin Med J (Engl). 2016;129(17): 2020-5. https://doi. org/10.4103/0366-6999.189068

23. Christe A, Walti L, Charimo J, Rauch A, Furrer H, Meyer A, Huynh-Do U, Heverhagen JT, Mueller NJ, Cavassini M, Mombelli $\mathrm{M}$, van Delden C, Frauenfelder T, Montet X, Beigelman-Aubry C, Arampatzis S, Ebner L. Imaging patterns of Pneumocystis jirovecii pneumonia in HIV-positive and renal transplant patients - a multicentre study. Swiss Med Wkly. 2019;149: w20130. https://doi.org/10.4414/smw.2019.20130

24. White PL, Backx M, Barnes RA. Diagnosis and management of Pneumocystis jirovecii infection. Expert Rev Anti Infect Ther. 2017;15(5): 435-447. https://doi.org/10.1080/14787210.2017. 1305887

25. She WH, Chok KSH, Li IWS, Ma KW, Sin SL, Dai WC, Fung JYY, Lo CM. Pneumocystis jirovecii-related spontaneous pneumothorax, pneumomediastinum and subcutaneous emphysema in a liver transplant recipient: a case report. BMC Infect Dis. 2019;19(1):66. https://doi.org/10.1186/s12879-0193723-y 